\title{
Triticum aestivum Antigen IgE Antibody Measurement
}

National Cancer Institute

\section{Source}

National Cancer Institute. Triticum aestivum Antigen IgE Antibody Measurement. NCI

Thesaurus. Code C147277.

The determination of the amount of Triticum aestivum antigen IgE antibody present in a sample. 